\title{
On Literary Creativity in the Discourse Dimension
}

\author{
Nalya Ovshieva ${ }^{l, *}$ \\ ${ }^{1}$ Department of German Philology, B.B. Gorodovikov Kalmyk State University, 1-71, microdistrict 6, 358014, Elista, Russia
}

\begin{abstract}
The paper deals with the strategies of foregrounding and defamiliarization as the techniques of literary creativity. The strategy of foregrounding, which can be achieved either via deviation or parallelism, is typically conceived as the deviation from daily language, and is closely associated with novelty and aesthetic appreciation. Whereas defamiliarization is viewed as the technique focusing on the unusual setting, or unexpected angle of vision to make it foregrounded. After the survey of different views of the above-mentioned strategies, an attempt is made to verify that both strategies are used to indicate the turning points in the story. However, in contradistinction to discourse markers, they operate indirectly in literary discourse, creating stylistic effects on the phonetic, grammatical, or semantic levels. The results of the analysis conducted on the basis of short stories by English-speaking authors will be presented in order to demonstrate that both techniques are mostly applied to indicate conflict or complication in the story.
\end{abstract}

\section{Introduction}

Our paper deals with the issue of literary creativity in English literary discourse. Literary creativity is conceived as imaginative or creative writing, considered from the point of style and effect. It is generally accepted to be implemented through foregrounding and defamiliarization.

Foregrounding can be achieved in one of two ways, either via deviation or parallelism. J. Douthwaite claims that "in many cases the type of deviation used may provide a strong clue as to the meaning the deviation intends to convey" [1]. The term "defamiliarization", launched by V. Shklovsky in his theory of prose [2], was borrowed from cinematography, and as P. K.W. Tan justly notes, "applied to verbal art to refer to all that is that is thrust into prominence for the reader or the audience" [3]. All of the above studies indicate that both concepts must be defined relative to the starting point for theorizing. D.S. Miall and D. Kuiken, for whom foregrounding is a starting point for exploring the interpretation process of literary texts, consider it as inducing defamiliarization, i.e., striking readers as interesting and capturing their attention [4]. V. B. Shklovsky, starting off from the concept of defamiliarization in his discussion, regards it as achieving foregrounding effect [2]. This definitional overlap can be accounted for by the fact that literary techniques are designed to create stylistic effects that amaze with their novelty and expressiveness.

The concept of foregrounding was introduced in the papers on literariness or literary creativity [4-5], which came out as a response to literary modernist writings in the early half of the 20th century. Though it is a technique to draw the reader's attention to a certain portion (or portions) of the text to indicate that something 'special' is happening there, it does not, however, tell us how to interpret deviation. To do that, the entire inferential engine must be put into action [1]. D.S. Miall and D. Kuiken applied an explanatory approach to the interpretation of stylistic experimentation of modernist writers in terms of "foregrounding" and "defamiliarization". They argue that "literariness is constituted when stylistic or narrative variations defamiliarize conventionally understood referents and prompt reinterpretive transformations of a conventional feeling or concept" [5]. In view of the above, the interpretation process was considered as an interactive process including three steps: foregrounding (i.e. stylistic or narrative variations made by the author) - defamiliarization (or readers' defamiliarizing responses to them) - reinterpretive transformations (or modification of personal meanings). This process seems relevant from the perspective of a reader, and fits in with the conception of literary discourse as an ambiguous text. However, the above-mentioned techniques need to be looked at from the perspective of a writer as well, i.e. be considered from the discourse perspective. In this respect, our research aims to explore how the strategies affect the construction of literary discourse.

\section{Materials and methods}

Thus, the aim of the work is to identify the specific features of literary creativity in English literary discourse, viz. investigate the strategies of foregrounding and defamiliarization in the discourse dimension. To achieve the aim, we have to clarify the content of the concepts mentioned above as there is no consensus on the subject. Moreover, we intend to find out what

\footnotetext{
* Corresponding author: nalya154@mail.ru
} 
contribution they make towards development of literary discourse.

We can distinguish three approaches, on the whole. So, for example, J. Mukarovsky, one of the representatives of the Prague School, argued that foregrounding was a systematic violation of standard conventions [6]. V. van Per and F. Hakemulder relate foregrounding to the sphere of stylistics and rhetoric. According to them, foregrounding is achieved through the range of stylistic effects that are created either on the phonetic (e.g., alliteration, rhyme), grammatical (e.g., inversion, ellipsis), or semantic (e.g., metaphor, irony) levels [4-6]. In parallelism, too, readers are assumed to see an invitation to search for meaning connections between the parallel structures, or contrastive meaning links [7]. Deviation from the norm is attributed to poetic creativity by them, and is regarded in relation to it as a tradition [8].

According to V.B. Shklovsky, the essence of the phenomenon of defamiliarization considerably comes down to the use of the essentially new - external viewpoint of a familiar thing or a familiar phenomenon when the artist "does not name a thing, but describes it as if seen for the first time, and an event - as if it had occurred for the first time " [9]. In other words, the technique of defamiliarization can be understood as the transition to the viewpoint of the external observer, ie the use of the position essentially external in relation to the phenomenon described.

In contradistinction to V. B. Shklovsky, D. S. Mial and D. Kuiken conceive defamiliarization as the psychological process. They point out the similarity between the strategies of foregrounding and defamiliarization, and consider the latter as a result achieved through the technique of foregrounding [4]. While investigating the psychological process that the reader undergoes in the process of interpreting foregrounding, D. S. Mial and D. Kuiken [4] argue that the constructive work begins at the moment when the readers of a literary text react emotionally in response to the elements that are interesting from the standpoint of stylistics. Thus, in such rethinking of the text an important role is played by the feelings that were evoked in response to these features [4].

J. Douthwaite describes foregrounding and defamiliarization as fundamental (global) high-order techniques. Deviation from the norm is interpreted in this case as a deliberate violation of the rule, deliberately masking "mistakes" of one kind or another, and parallelism - as repetition, ie as the multiple use of the linguistic characteristics: phonological, grammatical, graphological, thematic, etc. The application of the foregrounding strategy as the combination of deviation and parallelism is carried out, according to $\mathrm{J}$. Douthwaite, through the use of lower-level devices. In the sphere of grammar, such a technique could be, for example, a violation of word order in a sentence, in the sphere of graphology, the use of a lowercase letter in the first word or the capitalization of all words, etc. [10]. We can draw a parallel between literary creativity and linguistic creativity likewise: the devices of literary creativity operating as high-order techniques, whereas those of linguistic creativity - as lower-level ones, subservient to the former.

Thus, it is the distinction between foregrounding and defamiliarization that makes up the essence of literary creativity that imparts literariness to a work of fiction. Let us consider the linguistic means of achieving foregrounding:

No. 1

They left Europe behind, but they took as much of it along with them as possible. Several van-loads, as a matter of fact. All those adorable and irreplaceable "things". And all arrived in New York, idealists, child, and the huge bulk of Europe they had lugged along. [12]

Here the author uses metaphor in conjunction with antonomasia (the huge bulk of Europe) in order to create an ironic effect. After all, Valerie and Erasmus who considered themselves idealists were actually materialists who bought everything they could in Europe.

And further:

No. 2

She and Erasmus house-hunted. But alas! Their income was quite under three thousand dollars a year. They found - well, everybody knows what they found. Two small rooms and a kitchenette, and don't let us unpack a thing!

The chunk of Europe which they had bitten off went into a warehouse, at fifty dollars a month. And they sat in two small rooms and a kitchenette, and wondered why they'd done it. [12]

Here metaphor and antonomasia (the chunk of Europe) are used in conjunction with the metaphorical verb (had bitten off) in order to enhance the ironic effect. Indicating conflict of interests (love for Europe vs love for things) through lexical repetition (the huge bulk of Europe - the chunk of Europe), the author conveys the main idea: Valerie and Erasmus who were convinced that they were buying "things" out of love for art, actually pursued only mercantile interests.

No. 3

He felt the spell of Margharita Clayton. But he was not entirely sure about her ...

Such women could be, though innocent themselves, the cause of crimes.

Such women could be, in intent and design, criminals themselves, though not in action.

Theirs was never the hand that held the knife[13]

As to Margharita Clayton - no - he did not know!

Here Mrs. Clayton turns to Poirot to help free her beloved major Rich, accused of murdering her husband whose body was found in the chest in the living room.

The author skillfully indicates conflict of interests. Though Poirot felt the charm of Margharita Clayton, he thought that the femme fatale might have been the cause of her husband's death. Anaphora (Such women could be) is used in conjunction with syntactic parallelism (he was not entirely sure - he did not know) not so much to enhance the emotional excitement experienced by Poirot, but as an omen of the future development of the events.

No. 4 
And then I began to feel that dull, leaden, souldepressing sensation known as the sense of duty. Why should that sense fall upon one as a weight and a burden? I knew that I was doomed that day to give up the bulk of my store of hard-wrung coin to the relief of this Ada Lowery. But I swore to myself that Tripp's whiskey dollar would not be forthcoming. He might play knight-errant at my expense, but he would indulge in no wassail afterward, commemorating my weakness and gullibility. In a kind of chilly anger I put on my coat and hat. [14]

Here the narrator's friend, Tripp, asked him for a dollar, promising to help the journalist get the story. He told him a love story about a beautiful girl from Long Island who came to look for her boyfriend George in New York and was disappointed, not finding him. Tripp made the journalist meet the girl and talk to her. The author indicates conflict of interests: though in want of a story, the journalist is not willing to meet with the girl. The gradual increase in the strength of his feelings of irritation and anger is conveyed through gradation: a series of epithets (dull, leaden, soul-depressing), rhetorical question (Why should that sense ...?) and the emphatic verbs (was doomed, swore). Mr. Chalmers was reluctant to give the hard-earned money to Tripp. The focus on the psychological state of the main character, forcing himself to go to the meeting with the girl out of the sense of duty, is the way to create the twist in the plot because it is at the meeting where he learns that Tripp was the girl's boyfriend.

No.5

'I must have been - I must be - mad!' he thought. 'What came into me? Poor little Megan!' "God bless us all, and Mr. Ashes!" "I want to be with you - only to be with you!" And burying his face in his pillow, he smothered down a fit of sobbing. Not to go back was awful! To go back - more awful still!

Emotion, when you are young, and give real vent to it, loses its power of torture. And he fell asleep, thinking: 'What was it - a few kisses - all forgotten in a month!' [15]

Here the author shows us the contrast between people from different social classes. The romantic relationship between Frank Ashurst and Megan, a girl of the people, reaches a deadlock because it is bound to end up in their marriage. Frank Ashurst, a representative of the highermiddle class, a University graduate, is suffering in the search of the way out. The author indicates conflict of interests by using allusion (Not to go back was awful! To go back - more awful still) to the famous monologue "To be, or not to be, ..." from the drama by William Shakespeare "Hamlet". Though infatuated with the girl, Frank decides to stay with Stella Ashurst, a girl from his circle.

No. 6

The discreet door shut with a click. She was outside on the step, gazing at the winter afternoon. There was a cold bitter taste in the air, and the newlighted lamps looked sad. Sad were the lights in the houses opposite. Dimly they burned as if regretting something. There are moments, horrible moments in life, when one emerges from shelter and looks out, and it's awful. One oughtn't to give way to them. One ought to go home and have an extra-special tea. But at the very instant a young girl, thin, dark, shadowy - where had she come from? - was standing at Rosemary's elbow and a voice like a sigh, almost like a sob, breathed: "Madam, may I speak to you a moment?" [16]

The author indicates conflict between the rich and the poor by describing the street relative to the antique shop. After visiting the antique shop, Rosemary Fell, a rich young married woman, went outside. To describe the atmosphere of tension in the street, the author uses the technique of gradation: partial inversion (Sad were Dimly they burned), lexical repetition (There are moments, horrible moments in life), emphatic adjectives (horrible, awful, extra-special), as well as anaphora (One oughtn't - One ought). Gradation signals the possibility of complication in the story. Then, as we know, she was approached by Miss Smith, a poor girl who asked for the money to buy a cup of tea.

Let us consider the technique of defamiliarisation:

No. 7

Cecilia subsided weakly on to her rug, after the anguished tension of listening. Oh, it was awful. The sun shone, the sky was blue, all seemed so lovely and afternoony and summery. And yet, oh, horror! - she was going to be forced to believe in the supernatural! [17]

Here Cecilia who was sunbathing on the roof overheard her aunt Pauline's imaginary conversation with her late son Henry. Stunned, bewildered, she felt as if she saw what is before her eyes for the first time. The author indicates complication by contrasting the serenity of the day with the emotional state of the heroine, using creative derivation. The suffix $-\mathrm{y}$ is used in an unusual way to form adjectives from the nouns denoting periods of time (afternoony and summery).

No.8

The tired voice went on. It seemed to surmount enormous obstacles to speech. The man's sick, Colonel Crashaw thought, with pity and irritation. When a young man he had climbed in the Himalayas, and he remembered how at great heights several breaths had to be taken for every step advanced. The five-foot-high platform in the Music Rooms of The Spa seemed to entail for the speaker some of the same effort. He should never have come out on such a raw afternoon, thought Colonel Crashaw, pouring out a glass of water and pushing it across the lecturer's table. [18]

Here the author uses synecdoche (The tired voice went on), and personification (It seemed to surmount enormous obstacles to speech). Interestingly, the speaker's voice evokes the narrator's memories of his own ascent in the Himalayan mountains, which required from him the same great effort. The author indicates complication by describing the speaker's voice, which, paradoxically, creates the feeling that though we hear the voice, there is no man.

And further:

No.9

The rooms were badly heated, and yellow fingers of winter fog felt for cracks in the many windows. There was little doubt that the speaker had lost all touch with 
his audience. It was scattered in patches about the hallelderly ladies who made no attempt to hide their cruel boredom, and a few men, with the appearance of retired officers, who put a show of attention. [18]

Here the author indicates complication by using suspended metaphor (yellow fingers of winter fog felt for cracks in the many windows). The technique of foregrounding is used in conjunction with that of defamiliarization (No.8) to emphasize the oddity of the situation.

No. 10

"She was outlined against the sky, carrying a basket, and you could see that sky through the crook of her arm... The wind, blowing her dark frieze skirt against her legs, lifted her battered peacock tam-o'-shanter; her grayish blouse was worn and old, her shoes were split, her little hands rough and red, her neck browned... but her grey eyes were the wonder - dewy as if opened for the first time that day. " [15]

For the first time Frank saw Megan against the backdrop of the sky. The blue sky is always associated in the minds of people with spaciousness and purity. Besides, the girl's eyes were clean like the morning dew ("dewy as if opened for the first time that day"). So, the girl is perceived as part of nature, whereas nature, in turn, is perceived as an animate being (cf. "the wind, blowing her dark frieze skirt against her legs"). Here the author emphasizes the unity of the girl of the people with nature. The author indicates inception by contrasting purity and sincerity of Megan's feelings with Frank's pragmatism, which inevitably led to complication.

\section{Results and discussion}

Several recognized writers of the period, such as Evgenii Zamiatin, Isaak Babel', Viktor Shklovskii, Iurii Tynianov and Il' $f$ and Petrov became actively involved in film work by writing scenarios in the 1920s. Consequently, their own literary techniques were clearly inspired by film, such as those of the close-up, the fragmented narrative, and 'cinematic' visual metaphors [19]. The emphasis on the visual lending the writers' works a cinematic quality is consonant with the technique of defamiliarization viewed by V. Shklovsky not as approximation of meaning to our understanding, but as the creation of specific perception of the subject, the creation of its vision, rather than recognition [2]. The original meaning of the term "ostranenie" introduced by him was "lost in translation" though the term "defamiliarization" proved to be relevant to the description of the interpretation process.

In view of the above, and on basis of the analysis of short stories by English-speaking authors, I would like to argue that most writers of the period, irrespective of their writing style and literary inclinations, were influenced by cinematography and its techniques that had a significant effect on their work. They experimented with fragmentation of narrative, unexpected angles of vision, striking similes or visual metaphors in a similar vein. I dare say that it is thanks to cinematography and its techniques, adopted by the writers, that the reader was able to see something ordinary or eternal in a new light.

Therefore, it is the distinction between foregrounding and defamiliarization, rather than similarity between them, that makes up the essence of literary creativity. In this regard, the strategies of foregrounding and defamiliarization might be considered as the techniques of literary creativity that impart literariness to a work of fiction. Foregrounding can be achieved in one of two ways, either via deviation or parallelism. Defamiliarization is conceived, in accordance with the theory of prose by V. B. Shklovsky, as the technique focusing on the unusual setting, or unexpected angle of vision to make it foregrounded.

The analysis of the linguistic material made it possible to identify the goal achieved by both strategies, viz. to indicate the turning points in the story such as inception, conflict/complication, or climax.

\section{Conclusion}

In contradistinction to discourse markers, the strategies of literary creativity operate indirectly throughout the literary discourse. As shown by the analysis of the material, both techniques are mostly applied to indicate conflict or complication in the story. On the whole, the purpose of using the strategies of foregrounding and defamiliarization is to create a harmonious work of art that meets the requirements of art, and gives not only intellectual but also aesthetic pleasure to readers.

\section{References}

1. J. Douthwaite, Quaderni Di Palazzo Serra, Università degli Studi di Genova, The Power of Parallelism, 26, 97 (2014)

2. V. B. Shklovsky, On the theory of prose (Federation, Moscow, 1929)

3. P. K.W. Tan, The Routledge Handbook of Discourse Analysis, J. P. Gee, M. Handford (eds), Literary discourse, 630 (Routledge, Abingdon, Oxon, 2012)

4. D. S. Miall, D. Kuiken, Poetics, Foregrounding, Defamiliarization, and Affect: Response to Literary Stories, 22, 392-395 (1994)

5. D. S. Miall, D. Kuiken, Discourse Processes, What Is Literariness? Three Components of Literary Reading, 28 (2), 123 (1999)

6. J. Mukarovský, A Prague School reader on esthetics, literary structure, and style, P. L. Garvin (Ed.), Standard language and poetic language, 17-30 (Georgetown University Press, Washington, DC, 1964) (Original work published 1932.)

7. W. van Peer, J. Hakemulder, S. Zyngier, Language and Literature, Lines on feeling: Foregrounding, aesthetics and meaning, 16(2), 198. Retrieved from: http://www.sagepublications.com (2007)

8. W. van Peer, J. Hakemulder, Encyclopedia of Language and Linguistics K. Brown (ed.), 
Foregrounding, 546-547 (Oxford University Press, Oxford, 2006)

9. B.A. Uspensky, Poetics of composition. The structure of the literary text and the typology of the compositional form, 173-174 (Art, Moscow, 1970)

10. J. Douthwaite, Towards a linguistic theory of foregrounding (Edizioni dell'Orso, Alessandria, 2000).

11. I. A. Shchirova, Studia Linguistica, On the Concept and Role of Foregrounding, 24, 199 (Polytechnicprint, St. Petersburg, 2015)

12. D.H. Lawrence, English story of the $\mathrm{XX}$ century, Things, 192-193 (PH Manager, M., 2000)

13. A. Christie, Selected Detective Stories, The Mystery of the Spanish Chest, 29 (PH Manager, M., 2004)
14. O. Henry, Selected Stories, No Story, 135 (PH Manager, M., 2000)

15. J. Galsworthy, English story of the XX century, The Apple Tree, 60, 8 (PH Manager, M., 2000)

16. K. Mansfield, English story of the $\mathrm{XX}$ century, $A$ Cup of Tea, 40 (PH Manager, M., 2000)

17. D.H. Lawrence, English story of the XX century, The Lovely Lady, 177 (PH Manager, M., 2000)

18. G. Greene, English story of the XX century, Proof Positive, 33 (PH Manager, M., 2000)

19. M. Michalski, Russian Literature, Modernism and the Visual Arts, C. Kelly, S. Lovell (eds.), Ch. 8 Cinematic literature and literary cinema: Olesha, Room and the search for a new art form, 221-222 (Cambridge University Press, Cambridge, 2000) 